\title{
ИК поглощение света на оптических фононах наноструктур AIN с нанометровым пространственным разрешением
}

\author{
К.В. Аникин ${ }^{1}$, I.A. Milekhin ${ }^{2}$, А.Г. Милёхин ${ }^{1,3}$, В.Г. Мансуров², Т.В. Малин², К.С. Журавлев ${ }^{2}$, \\ D.R.T. Zahn ${ }^{2}$, A.B. Латышев ${ }^{1,3}$ \\ ${ }^{1}$ Институт физики полупроводников им. А.В. Ржанова СО РАН, Новосибирск, 630090, \\ пр. ак. Лаврентьева, 13 \\ ${ }^{2}$ Semiconductor Physics, Chemnitz University of Technology, D-09107 Chemnitz, Germany \\ ${ }^{3}$ Новосибирский государственный университет, 630090, Пирогова \\ тел:+7 (383) 316-60-54, факс:+7 (383) 333-2771, эл.nочта: anikin@isp.nsc.ru
}

DOI 10.34077/RCSP2021-160

Сообщается об исследовании фононного спектра одиночных наноструктур AlN с помощью ИК спектроскопии с пространственным разрешением в несколько десятков нанометров.

В работе исследовались два типа образцов: (1)- вертикально стоящие гексагональные наноколонны AlN с латеральным размером около 300 нм и высотой 25 нм, сформированные методом аммиачной молекулярно-лучевой эпитаксии на поверхности слоя AIN на кремниевой подложке, (ось с перпендикулярна плоскости образа) и (2)- наноколонны AlN диаметром около 200 нм. и длиной до нескольких нанометров, лежащие на поверхности золота (ось с направлена вдоль поверхности образца), полученные эпитаксией из газовой фазы.

Регистрация спектров нано-ИК поглощения от индивидуальных наноколонн проводилась на сканирующем ближнепольном оптическом микроскопе s-SNOM NeaSpec, в качестве зонда использовалась металлическая игла (Pt/Ir: 95/5) атомно-силового микроскопа (ACM) с радиусом кривизны не более 25 нм. Нано-зонд выступает в качестве локального источника возбуждения, позволяя выполнять картирование ИК рассеяния/поглощения с нанометровым пространственным разрешением.

На рис.1 показано АСМ изображение образца типа (1), где стрелкой отмечено направление сканирования, ИК спектры для которой приведены на рис.2. В ИК спектрах образцов можно выделить две основные полосы в спектральной области 720-850 см-1. При этом при сканировании образца наблюдается сдвиг одной из полос в диапазоне $720-780 \mathrm{~cm}^{-1}$, в то время как полоса с центром в 830 $\mathrm{cm}^{-1}$ не меняет своего положения. Аналитические расчеты позволяют идентифицировать наблюдаемые в эксперименте линии как локально возбуждаемые моды поверхностных фононных поляритонов. При этом линии объемных фононов в экспериментальных спектрах не проявляются.

Для объяснения изменения частот фононных линий при сканировании поперек гексагона были проведены аналитические расчеты дисперсионных зависимостей $\mathrm{A}_{1}$ и $\mathrm{E}_{1}$ мод для наноколонн в приближении бесконечного цилиндра. Результаты расчетов позволяют предположить, что сдвиг полосы связан с проявлением анизотропии кристалла при сканировании боковой поверхности гексагона AlN.

Для проверки гипотезы о влиянии анизотропии на частоты фононов, были проведены измерения образцов типа 2, подтвердившие данное предположение.

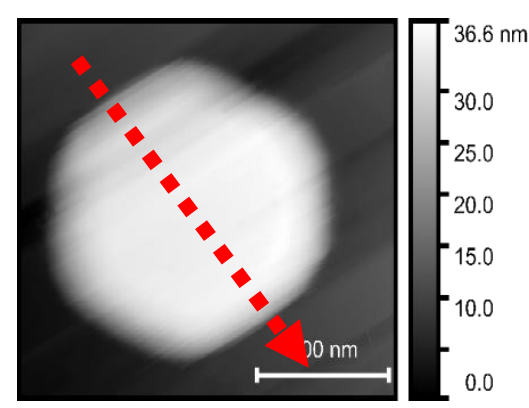

Рис.1. АСМ изображение образца.

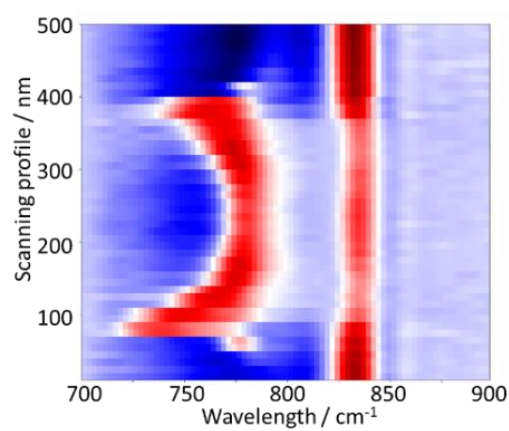

Рис.2. ИК спектры поглощения, измеренные вдоль направления, показанного на Рис.1.

Работа была выполнена при финансовой поддержке РФФИ (проект 18-29-20066). 